\title{
Soil-application of Zinc-EDTA Increases Leaf Photosynthesis of Immature 'Wichita' Pecan Trees
}

\author{
Richard J. Heerema ${ }^{1}$ \\ Department of Plant and Environmental Sciences, New Mexico State University, Las Cruces, NM \\ 88003 \\ Dawn VanLeeuwen
Economics, Applied Statistics, and International Business Department, New Mexico State University,
Las Cruces, NM 88003 \\ Marisa Y. Thompson \\ Department of Plant and Environmental Sciences, New Mexico State University, Las Cruces, NM \\ 88003
}

\author{
Joshua D. Sherman \\ Cooperative Extension Service, University of Arizona, Willcox, AZ 85643
}

Mary J. Comeau and James L. Walworth

Department of Soil, Water and Environmental Science, University of Arizona, Tucson, AZ 85719

Additional INDEX words. Carya illinoinensis, carbon assimilation, gas exchange, nutrient deficiency, micronutrient

\begin{abstract}
Zinc deficiency is common in pecan (Carya illinoinensis) grown in alkaline, calcareous soils. Zinc (Zn)deficient pecan leaves exhibit interveinal chlorosis, decreased leaf thickness, and reduced photosynthetic capacity. Low photosynthesis $\left(P_{n}\right)$ contributes to restricted vegetative growth, flowering, and fruiting of $Z$ n-deficient pecan trees. Our objectives were to measure effects of soil-applied ethylenediaminetetraacetic acid (EDTA)-chelated Zn fertilizer on gas exchange of immature 'Wichita' pecan and characterize the relationship between leaf $\mathrm{Zn}$ concentration and $P_{n}$. The study orchard had alkaline and calcareous soils and was planted in Spring 2011. Zinc was applied throughout each growing season as Zn EDTA through microsprinklers at rates of 0 (Control), 2.2, or $4.4 \mathrm{~kg} \cdot \mathrm{ha}^{-1} \mathrm{Zn}$. Leaf gas exchange and SPAD were measured on one occasion in the 2012 growing season, four in 2013 , and five in 2014. Soil Zn-EDTA applications significantly increased the leaf tissue $\mathrm{Zn}$ concentration throughout the study. On all measurement occasions, net $P_{n}$ was significantly increased by soil-applied $Z n$ EDTA compared with the control, but $P_{n}$ was not different between the two soil-applied $Z n$-EDTA treatments. Leaf $P_{n}$ in midseason did not increase at leaf tissue $\mathrm{Zn}$ concentrations above $14-22 \mathrm{mg} \cdot \mathrm{kg}^{-1}$. Leaf SPAD consistently followed a similar pattern to $P_{n}$. Soil $Z n-E D T A$ application increased leaf stomatal conductance $\left(g_{s}\right)$ compared with the Control early through midseason but not after August. Intercellular $\mathrm{CO}_{2}$ concentration was significantly lower for $\mathrm{Zn-EDTA-treated} \mathrm{trees}$ than the Control even on dates when there was no significant difference in $g_{s}$, which suggests that soil application of Zn-EDTA alleviated nonstomatal limitations to $P_{n}$ caused by $Z n$ deficiency.
\end{abstract}

The native range for pecan extends through much of the south-central United States and into scattered locations in Mexico. Native pecan groves are found growing in deep, sandy, alluvial soils in river bottoms. The soils that cover most of the native range of this tree species are acidic with $\mathrm{pH}$ levels below 6.0 , although in the westernmost native range soil $\mathrm{pH}$ may exceed 7.0 [U.S. Department of Agriculture (USDA), 2016a; U.S. Geological Survey, 2016]. Since the 1930s, and especially in the last 40 years, improved cultivar pecan orchard plantings in North America have expanded considerably into the semiarid western region, especially in the U.S. states of Texas, New Mexico, and Arizona, and the Mexican states of Chihuahua, Sonora, and Coahuila. Currently, there are at least 100,000 ha of

Received for publication 23 Sept. 2016. Accepted for publication 9 Dec. 2016. We thank Farmers Investment Company (FICO) for generously allowing us to conduct our research in their pecan orchard and Fertizona for their donations of zinc fertilizer. This study was made possible by Arizona Pecan Growers Association, Arizona Department of Agriculture, New Mexico State University Agricultural Experiment Station, and USDA-NIFA via Hatch funds.

${ }^{1}$ Corresponding author. E-mail: rjheerem@nmsu.edu. pecan orchards in the semiarid region of North America (Servicio de Información Agroalimentaria y Pesquera, 2014; USDA, 2012). In this region, soil $\mathrm{pH}$ generally ranges from 7.0 to 8.5 (USDA, 2016a).

A major challenge with growing pecans in the semiarid region is the widespread occurrence of calcareous and alkaline soils in which micronutrients, particularly $\mathrm{Zn}$, are poorly available for uptake (Fenn et al., 1990; Imtiaz et al., 2006; Marschner, 1993). Zinc deficiency was first identified in pecan and other fruit tree species in the 1930s (Alben et al., 1932a, 1932b; Chandler, 1937). Zinc deficiency in pecan is characterized by shortened internodes (giving rise to shoots with a rosette appearance), severely reduced leaf area, wavy leaf margins, interveinal leaf chlorosis and necrosis, and shoot terminal dieback (Alben et al., 1932a; Heerema, 2013). Along with reduced leaflet area, Ojeda-Barrios et al. (2012) showed that in Zn-deficient pecan, the leaves were thinner (particularly the palisade parenchyma cell layer), had higher stomatal numbers per square millimeter leaf area, and had disorganized spongy parenchyma cell layers. 
In bearing-age orchards, nut yields are reduced by $\mathrm{Zn}$ deficiency through its detrimental effects on pistillate flower production, the number of nuts set and matured, and final individual nut weight ( $\mathrm{Hu}$ and Sparks, 1990). In addition, there are major reductions in commercially important pecan nut quality parameters such as percentage kernel weight, total inshell nut volume, and percentage of fruits with dehisced shucks related to increasingly severe $\mathrm{Zn}$ deficiency ( $\mathrm{Hu}$ and Sparks, 1990). In young Zn-deficient pecan orchards, tree survival rates may be reduced (J.L. Walworth and R.J. Heerema, personal observation) and surviving trees are slow to establish and produce nuts (Walworth et al., 2016).

Zinc is an essential enzyme cofactor in a wide range of biochemical pathways in plants (Broadley et al., 2012, 2007; Brown et al., 1993; Vallee and Auld, 1990), so the effects of insufficient $\mathrm{Zn}$ on overall pecan tree function are extremely complex. Nevertheless, a substantial part of the reduction in shoot growth and fruit production in $\mathrm{Zn}$-deficient plants may be explained by the negative impacts of $\mathrm{Zn}$ deficiency on carbon assimilation. A strong reduction in leaf $\mathrm{P}_{\mathrm{n}}$ in response to $\mathrm{Zn}$ deficiency has been shown across a broad diversity of plant species (e.g., Amiri et al., 2016; Fu et al., 2015; Mattiello et al., 2015; Tavallali et al., 2009), including pecan (Hu and Sparks, 1991). Zinc has been proposed to have major effects on $P_{n}$ in a number of different ways, including its essential roles in the function of the carbonic anhydrase enzyme, which assists in movement of $\mathrm{CO}_{2}$ to the site of the Calvin cycle in the chloroplast stroma, and the $\mathrm{Cu}-\mathrm{Zn}$ superoxide dismutase enzyme, which is involved in protection of plant cells against oxidative damage by reactive oxygen species (Broadley et al., 2012; Cakmak, 2000; Yruela, 2013). Zinc may have further impacts on $\mathrm{P}_{\mathrm{n}}$ through its involvement in the regulation of guard cell function (Cakmak, 2000; Sharma et al., 1995) and photoassimilate export from leaves via the phloem (Cakmak, 2000).

During the first 2 or 3 months of each growing season, pecan producers in the semiarid production area typically make three to eight foliar spray applications of $\mathrm{Zn}$ sulfate to maintain

Table 1. Soil test levels in the 'Wichita' pecan orchard in 2011, before initiation of ethylenediaminetetraacetic acid-chelated zinc fertilizer treatments to soil.

\begin{tabular}{llll}
\hline Soil test & \multicolumn{1}{c}{ Method } & \multicolumn{1}{c}{ Result } & Rating \\
\hline $\mathrm{pH}$ & $1: 1$ soil:water & 8.1 & High \\
$\mathrm{EC}$ & $1: 1$ soil:water & $0.49 \mathrm{dS} \cdot \mathrm{m}^{-1}$ & Low \\
Calcium & $\mathrm{NH}_{4} \mathrm{OAc}(\mathrm{pH} 8.5)$ & $3,200 \mathrm{mg} \cdot \mathrm{kg}^{-1}$ & Very high \\
Magnesium & $\mathrm{NH}_{4} \mathrm{OAc}(\mathrm{pH} 8.5)$ & $140 \mathrm{mg} \cdot \mathrm{kg}^{-1}$ & High \\
Sodium & $\mathrm{NH}_{4} \mathrm{OAc}(\mathrm{pH} 8.5)$ & $66 \mathrm{mg} \cdot \mathrm{kg}^{-1}$ & Medium \\
Potassium & $\mathrm{NH}_{4} \mathrm{OAc}(\mathrm{pH} 8.5)$ & $380 \mathrm{mg} \cdot \mathrm{kg}^{-1}$ & High \\
Zinc & DTPA & $0.39 \mathrm{mg} \cdot \mathrm{kg}^{-1}$ & Low \\
Iron & DTPA & $1.9 \mathrm{mg} \cdot \mathrm{kg}^{-1}$ & Low \\
Manganese & DTPA & $11 \mathrm{mg} \cdot \mathrm{kg}^{-1}$ & High \\
Copper & DTPA & $0.83 \mathrm{mg} \cdot \mathrm{kg}^{-1}$ & High \\
Nickel & DTPA & $0.14 \mathrm{mg} \cdot \mathrm{kg}^{-1}$ & No standards \\
Nitrate-nitrogen & Cadmium reduction & $23 \mathrm{mg} \cdot \mathrm{kg}^{-1}$ & Medium \\
Phosphate-phosphorus & Olsen & $7.9 \mathrm{mg} \cdot \mathrm{kg}^{-1}$ & Low \\
Sulfate-sulfur & Hot water & $18 \mathrm{mg} \cdot \mathrm{kg}^{-1}$ & High \\
Boron & Hot water & $0.37 \mathrm{mg} \cdot \mathrm{kg}^{-1}$ & Medium \\
Free lime & Acid test & High & \\
Exchangeable sodium percentage & Calculated & $1.6 \%$ & \\
Cation exchange capacity & Calculated & $18.4 \mathrm{cmol} \cdot \mathrm{kg}^{-1}$ & \\
\hline
\end{tabular}

$\mathrm{NH}_{4} \mathrm{OAc}=$ ammonium acetate; DTPA $=$ diethylenetriaminepentaacetic acid; $\mathrm{EC}=$ electrical conductivity. adequate $\mathrm{Zn}$ in nut-producing trees (Heerema, 2013). Young, rapidly growing trees may be sprayed weekly during the active growing season. When canopy spray coverage is good and not too much time elapses between $\mathrm{Zn}$ applications, foliar $\mathrm{Zn}$ sprays are generally effective in preventing development of visible foliar Zn deficiency symptoms in pecan, but weather conditions (e.g., wind and precipitation) and conflicting orchard operations (e.g., flood irrigation) often interfere with $\mathrm{Zn}$ spray operations. Thus, $\mathrm{Zn}$ deficiency remains one of the most important factors limiting pecan orchard nut production and profitability across the North American semiarid growing region.

In the semiarid region, there is strong interest among pecan producers in developing an effective method for managing $\mathrm{Zn}$ nutrition through soil fertilizer application and a number of published studies have shown promising options (Fenn et al., 1990; Núñez-Moreno et al., 2009a, 2009b). We began a longterm experiment in 2011 to evaluate the use of soil-applied EDTA-chelated $\mathrm{Zn}$ fertilizer for managing $\mathrm{Zn}$ nutrition in an immature 'Wichita' pecan orchard grown on a calcareous, alkaline soil. The objectives in the current study were 2-fold: the first experimental objective was to measure how soilapplied Zn-EDTA affects leaf gas exchange of immature 'Wichita' pecan and the second was to characterize the relationship between leaf $\mathrm{Zn}$ concentration and $\mathrm{P}_{\mathrm{n}}$.

\section{Materials and Methods}

STUdY SITE AND ZINC TREATMENTS. This study was conducted in a commercial pecan orchard planted in 2011 near San Simon, AZ (lat. $32^{\circ} 15^{\prime} 20.2^{\prime \prime} \mathrm{N}$, long. $109^{\circ} 10^{\prime} 29.8^{\prime \prime} \mathrm{W}$, elevation $1118 \mathrm{~m}$ ). The climate is semiarid with an average of $<30 \mathrm{~cm}$ precipitation annually. A weather station near the orchard site showed total annual precipitation of $17.0,21.4$, and $24.8 \mathrm{~cm}$ for 2012 , 2013, and 2014, respectively, with well over $50 \%$ of the total precipitation falling as rain during the months of July, August, and September in each of those years (University of Arizona, 2016). On average, the region has a frost-free period of $\approx 210 \mathrm{~d}$ (USDA, 2016b). The main cultivar in the orchard is Wichita budded on open-pollinated seedling Ideal (synonym Bradley) rootstocks with $25 \%$ Western (synonym Western Schley) cultivar pollinizers. 'Wichita' is one of the most widely grown cultivars in the semiarid region and is known to be more prone than many other popular pecan cultivars to develop $\mathrm{Zn}$ deficiencies when grown in calcareous, alkaline soils (Herrera, 2005). Tree spacing was $6 \times 12 \mathrm{~m}$. The soil in the orchard is a Guest silty clay loam (fine, mixed, superactive, calcareous, and thermic Ustertic Torrifluvents) with alkaline pH (USDA, 2011, 2016a). Soil test values at initiation of the study are shown in Table 1.

The orchard owner managed all orchard operations except Zn fertilizer applications. Each tree was 


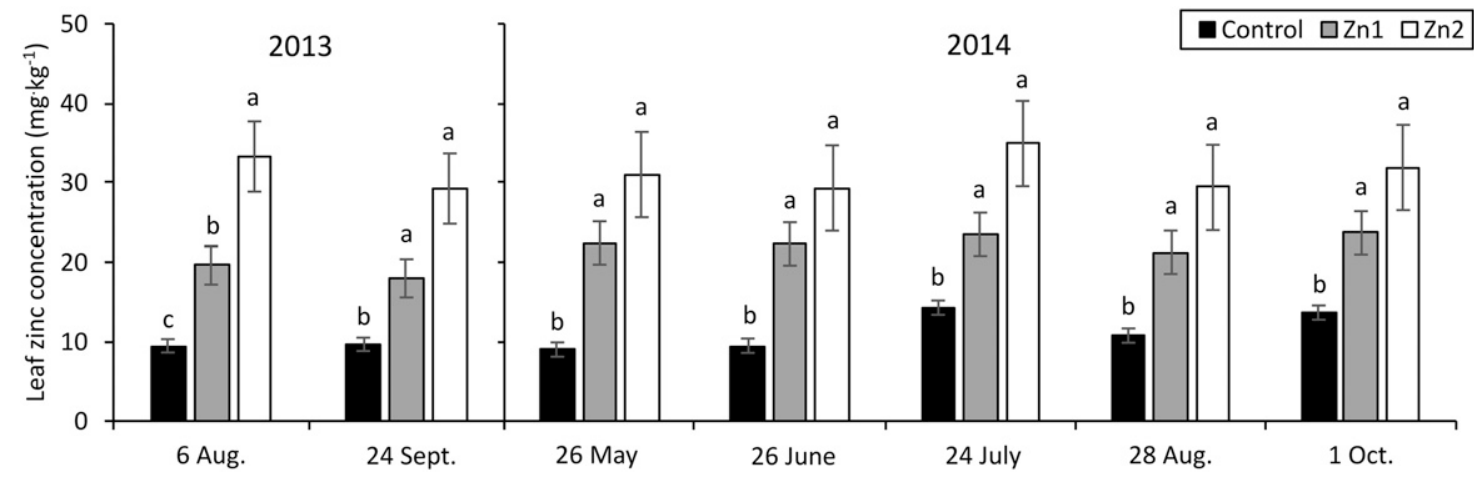

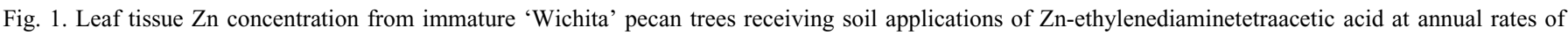
$2.2 \mathrm{~kg} \cdot \mathrm{ha}^{-1} \mathrm{Zn}\left[\mathrm{Zn} 1\right.$ (gray bars)] or $4.4 \mathrm{~kg} \cdot \mathrm{ha}^{-1} \mathrm{Zn}$ [Zn2 (white bars)] beginning in 2011. Trees in the Control (black bars) received no Zn fertilizer. Data are least squares means \pm model-based SE. Within measurement occasion (date), least squares means accompanied by the same lower-case letter are not significantly different $(\alpha=0.05)$ by F-protected least significant difference. The soil $\mathrm{Zn}$ treatment by date interactions for $\mathrm{Zn}$ concentration were not significant in $2013(P=$ $0.07)$ or $2014(P=0.17)$. The patterns of statistical significance according to the original analysis with constant treatment variance differed on two dates from the analysis with nonconstant treatment variance presented here. In the original analysis, least squares means for Control, Zn1, and $\mathrm{Zn} 2$ on 24 Sept. 2013 were accompanied by the lower-case letters c, b, and a, respectively. On 24 July 2014, least squares means for the Control, Zn1, and Zn2 were accompanied by the letters $\mathrm{b}, \mathrm{b}$, and $\mathrm{a}$, respectively.
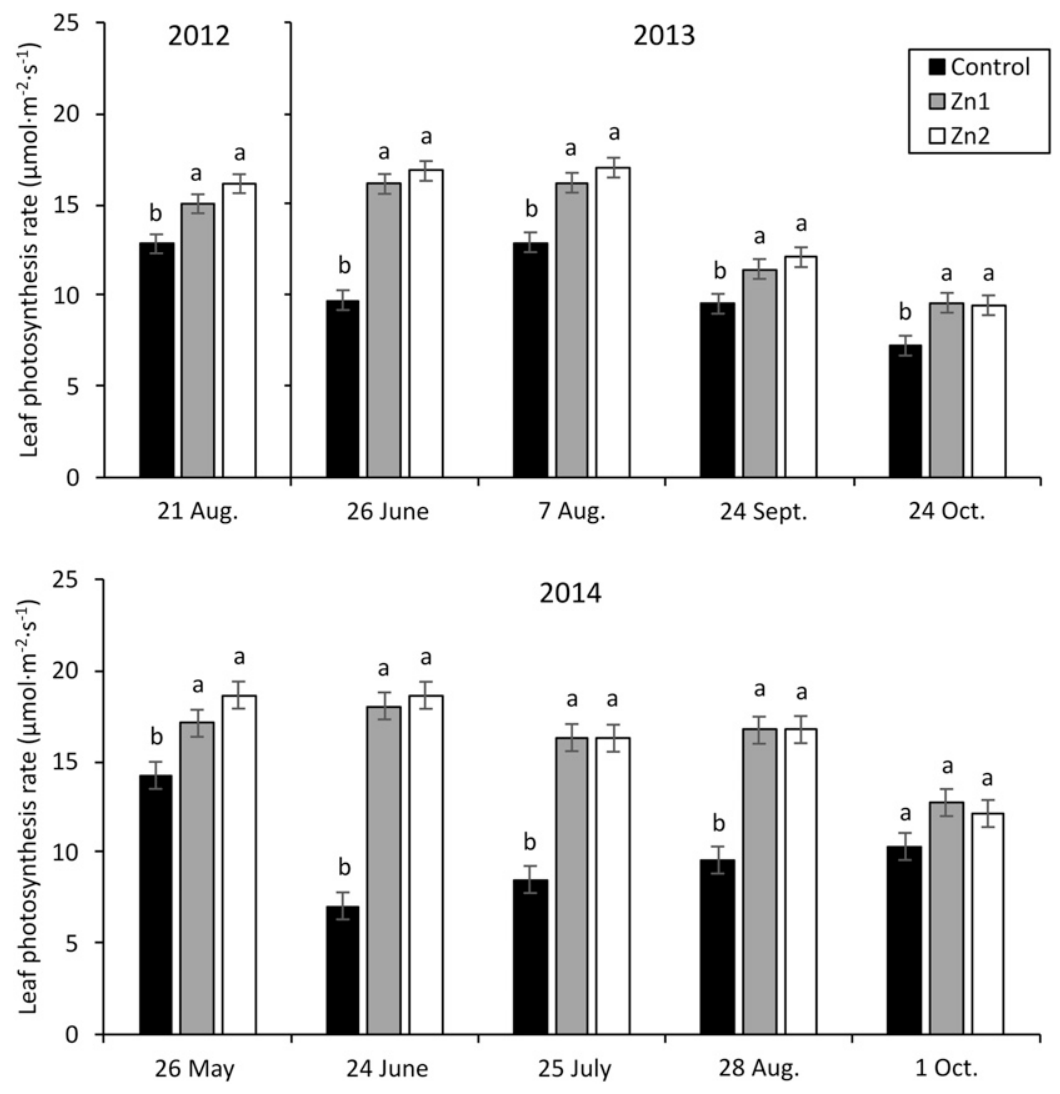

Fig. 2. Net photosynthesis of leaves from immature 'Wichita' pecan trees receiving soil applications of Zn-ethylenediaminetetraacetic acid at annual rates of $2.2 \mathrm{~kg} \cdot \mathrm{ha}^{-1} \mathrm{Zn}$ [Zn1 (gray bars)] or $4.4 \mathrm{~kg} \cdot \mathrm{ha}^{-1}$ $\mathrm{Zn}$ [Zn2 (white bars)] beginning in 2011. Trees in the Control (black bars) received no $\mathrm{Zn}$ fertilizer. Data are least squares means \pm model-based SE. Within measurement occasion (date), least squares means accompanied by the same lower-case letter are not significantly different $(\alpha=0.05)$ by F-protected least significant difference.

irrigated by one microsprinkler with a wetted area $\approx 2.5 \mathrm{~m}$ diameter. Trees received $\approx 1 \mathrm{~m}$ of irrigation water each season. Weeds in the tree row were controlled with glyphosate $(3.5$ $\left.\mathrm{L} \cdot \mathrm{ha}^{-1}\right)$ four times, carfentrazone $\left(150 \mathrm{~mL} \cdot \mathrm{ha}^{-1}\right)$ twice, and glufosinate $\left(3.5 \mathrm{~L} \cdot \mathrm{ha}^{-1}\right)$ once per season. Areas between rows were mechanically mowed to suppress weeds. All trees were fertilized uniformly with $16 \mathrm{~N}-3.5 \mathrm{P}-2.5 \mathrm{~K}-4 \mathrm{~S}$ injected into the irrigation system at annual application rates of 247,493 , and $740 \mathrm{~kg} \cdot \mathrm{ha}^{-1}$ in 2012, 2013, and 2014, respectively.

Beginning the year of planting, trees in the study were supplied Zn-EDTA fertilizer (Sequestar 9\% Zn Chelate; Monterey Ag Resources, Fresno, CA) by injection through the orchard microsprinkler irrigation system at one of three rates: 0 (Control), $2.2(\mathrm{Zn} 1)$, or $4.4(\mathrm{Zn} 2) \mathrm{kg} \cdot \mathrm{ha}^{-1} \mathrm{Zn}$ per year. In the first 3 years of the study, Zn-EDTA applications were distributed across the whole growing season (on 13, 14, and 16 irrigation dates from Apr. to Oct. in 2011, 2012, and 2013, respectively). In 2014, ZnEDTA applications were distributed across eight irrigations dates only during the first half of the growing season (April-July). Within each season, soil Zn-EDTA applications were split evenly among application dates. No foliar $\mathrm{Zn}$ applications were made. The study was a randomized complete block design (RCBD) with four blocks. Each plot contained at least 15 trees (at least 45 trees per block).

Gas eXChange Measurements AND LEAF TISSUE SAMPLING. In Summer 2012, four trees were selected per $\mathrm{Zn}$ treatment in each block for gas exchange measurements (48 trees total). Within each $\mathrm{Zn}$ treatment, trees were selected based on uniformity of general appearance of health and tree size. The same trees were used throughout the study. On one date in 2012 (21 Aug.), four occasions in 2013 (25 June, 6 and 7 Aug., 24 Sept., and 24 Oct.) and five occasions in 2014 (26 May, 26 June, 24 and 25 July, 28 Aug., and 1 Oct.) leaf gas exchange was 

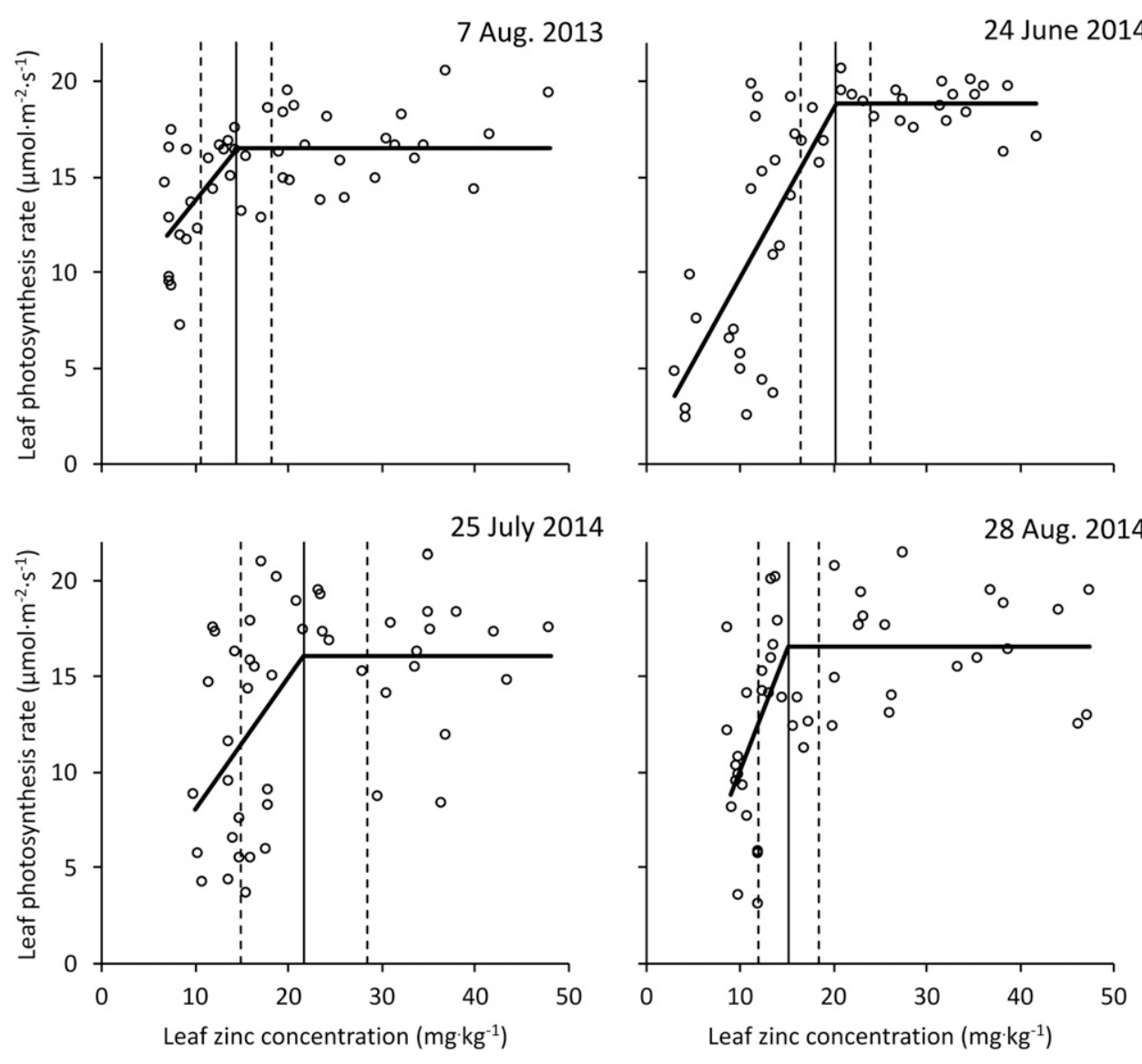

Fig. 3. The relationship of leaf net photosynthesis to leaf Zn concentration (by dry weight) in 'Wichita' pecan trees on 7 Aug. $2013\left(r^{2}=0.36\right)$, 24 June $2014\left(r^{2}=0.65\right), 25$ July $2014\left(r^{2}=0.26\right)$, and 28 Aug. $2014\left(r^{2}=0.34\right)$ measurement occasions. The solid vertical line represents the breakpoint leaf $\mathrm{Zn}$ tissue concentration below which leaf photosynthesis begins to decline. Dashed vertical lines represent the $95 \%$ confidence interval for the breakpoint.

measured on a middle leaflet of two sunlight-exposed leaves per tree. The leaves used for gas exchange measurement were visually representative of the overall level of symptom severity of $\mathrm{Zn}$ deficiency for the tree. On two measurement occasions, one in Aug. 2013 and another in July 2014, weather conditions did not allow for all of the gas exchange measurements to be made in the same day, so the remaining measurements were made the following morning.

Gas exchange measurements were made with a portable $\mathrm{P}_{\mathrm{n}}$ system (LI-6400XT; LI-COR, Lincoln, NE) equipped with a red/blue light-emitting diode light source (6400-02B; LI$\mathrm{COR}$ ) and $\mathrm{CO}_{2}$ injector system (6400-01; LI-COR). Chamber photosynthetically active radiation $(P A R)$ was held at 1700 $\mu \mathrm{mol} \cdot \mathrm{m}^{-2} \cdot \mathrm{s}^{-1}$. Light saturation of $\mathrm{P}_{\mathrm{n}}$ has been reported for pecan at PAR 1500 to $1700 \mu \mathrm{mol} \cdot \mathrm{m}^{-2} \cdot \mathrm{s}^{-1}$ (Anderson, 1994; Lombardini et al., 2009). Reference $\mathrm{CO}_{2}$ concentration was maintained near the global mean atmospheric concentration at $400 \mu \mathrm{mol} \cdot \mathrm{mol}^{-1}$ (U.S. Department of Commerce, 2016). Gas exchange data for each leaf were logged when both $\mathrm{P}_{\mathrm{n}}$ and $g_{\mathrm{S}}$ had stabilized, typically $30-60 \mathrm{~s}$ after the chamber was clamped onto the leaf. Immediately after measuring gas exchange of a leaf, a portable chlorophyll meter (SPAD 502; Konica Minolta, Ramsey, NJ) was used to measure greenness midway between the midrib and margin of the same leaflet. Gas exchange measurements were made between $\approx 0900$ and $1300 \mathrm{HR}$.
Physiological water status of one tree in each plot was measured as midday stem water potential [MDSWP (Shackel et al., 1997)] between $\approx 1300$ and 1500 HR on each gas exchange measurement date. One shaded leaf in the lower, interior portions of each tree canopy was placed in a sealed reflective bag for at least $20 \mathrm{~min}$ before leaf water potential was measured with a Scholander pressure chamber (PMS Instrument Co., Albany, OR). Except in Oct. 2013, average MDSWPs throughout the study ranged from -0.3 to $-0.6 \mathrm{MPa}$ (data not presented), indicating that the trees were not water stressed on those dates (Othman et al., 2014). On 24 Oct. 2013, the average MDSWP was $-1.2 \mathrm{MPa}$, which indicates that on that date the trees were under physiological water stress severe enough to negatively affect $P_{n}$ (Othman et al., 2014).

In 2012, leaflets for tissue nutrient analyses were collected on only one date (14 Aug.) and samples were pooled across all 'Wichita' trees in each plot. In 2013, separate leaf tissue samples were collected for $\mathrm{Zn}$ analysis from each of the trees used for gas exchange measurements on the August and September measurement dates and, in 2014, tissue samples were similarly collected on all of the measurement dates. With each tissue sampling in 2013 and 2014, 16 leaflets were collected per tree according to the method recommended by the University of Arizona and New Mexico State University Extension Services (Heerema, 2013; Walworth et al., 2006). Leaflet samples were first washed in a water bath with a phosphorus-free detergent $(0.05 \%$ detergent $)$, followed by rinses in deionized water and a rinse in dilute hydrochloric acid $(1 \% \mathrm{HCl})$, and finally one additional rinse with ultrapure water. Leaflets were spun to remove excess water, dried in an oven for $3 \mathrm{~d}$ at $65^{\circ} \mathrm{C}$, and mechanically ground to 20 -mesh particle size.

Tissue samples were dry ashed by placing 0.5 -g subsamples into $30-\mathrm{mL}$ porcelain crucibles, ramping the temperature to $500{ }^{\circ} \mathrm{C}$ over $3.5 \mathrm{~h}$ and maintaining the temperature for $5.5 \mathrm{~h}$ (Jones and Case, 1990). Cooled ash was dissolved in $10 \mathrm{~mL}$ of 2.0 $\mathrm{N} \mathrm{HCl}$, allowed to sit for several hours, diluted to $50 \mathrm{~mL}$, and allowed to sit overnight. Zinc concentration was analyzed with an atomic absorption spectrophotometer (3100; PerkinElmer, Waltham, MA) at a wavelength of $213.86 \mathrm{~nm}$.

Statistics. For each response variable $\left[\mathrm{P}_{\mathrm{n}}, \mathrm{SPAD}, g_{\mathrm{s}}\right.$, transpiration, intercellular $\mathrm{CO}_{2}$ concentration $\left(\mathrm{C}_{\mathrm{i}}\right)$, and tissue $\mathrm{Zn}$ concentration], analysis was conducted on plot averages. The 2012 data were analyzed as an RCBD with fixed blocks. Data for 2013 and 2014 were analyzed separately as RCBDs with repeated measures. Block, Zn treatment, date, block $\times$ date 

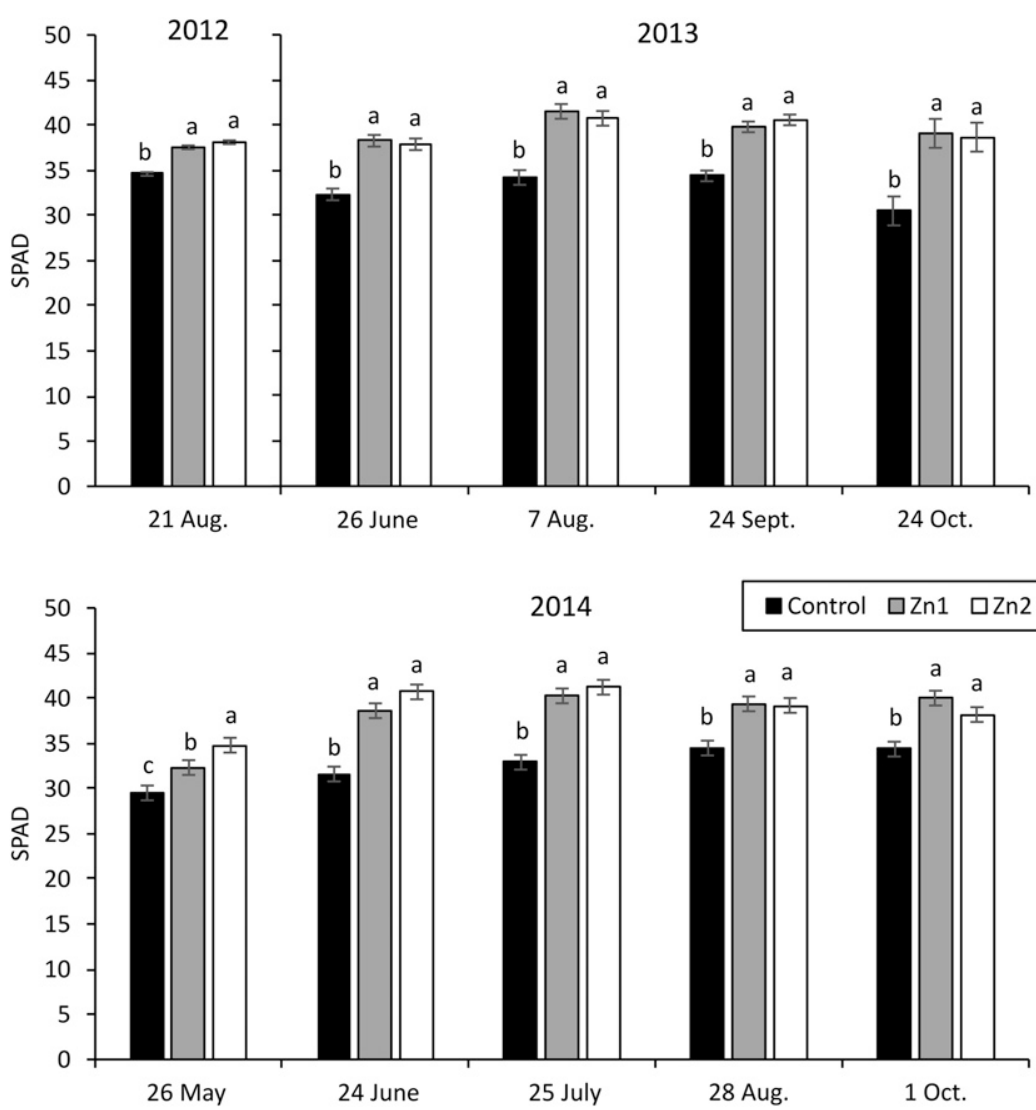

Fig. 4. SPAD values of leaves from immature 'Wichita' pecan trees receiving soil applications of Zn-ethylenediaminetetraacetic acid at annual rates of $2.2 \mathrm{~kg} \cdot \mathrm{ha}^{-1} \mathrm{Zn}$ [Zn1 (gray bars)] or $4.4 \mathrm{~kg} \cdot \mathrm{ha}^{-1}$ $\mathrm{Zn}$ [Zn2 (white bars)] beginning in 2011. Trees in the Control (black bars) received no Zn fertilizer. Data are least squares means \pm model-based SE. Within measurement occasion (date), least squares means accompanied by the same lower-case letter are not significantly different $(\alpha=0.05)$ by F-protected least significant difference. The soil $\mathrm{Zn}$ treatment by date interaction for SPAD was not significant in $2013(P=0.57)$

interaction, and $\mathrm{Zn}$ treatment $\times$ date interaction were included as fixed effects. To account for repeated measures through time, compound symmetric (CS), heterogeneous compound symmetric, spatial power (date) + plot random effect, and unstructured covariance structures were considered. Analysis proceeded using the covariance structure that produced the lowest Akaike information criteria (AICC) with a finite sample size correction value. Because comparing $\mathrm{Zn}$ treatments at each date was preplanned, slices were used to compare treatment means at each date. For dates where treatments differed, pairwise treatment comparisons were conducted. Analyses where the $\mathrm{Zn}$ treatment main effect was significant but not the treatment by date interaction are noted with treatment estimates averaged across date reported in the text. Leaf tissue $\mathrm{Zn}$ concentration exhibited different treatment group variances. To assess sensitivity of findings from the preplanned analysis to nonconstant treatment variances, an analysis with fixed effects for $\mathrm{Zn}$ treatment, date, and their interaction and fitting separate CS covariance structures to each treatment group was conducted; SEs from this analysis are presented. Discrepancies between the two analyses in the pattern of significance are noted. Data were analyzed using PROC MIXED software (version 9.3; SAS Institute, Cary, NC) and significance was defined at $P \leq 0.05$.
Following a preliminary analysis to assess whether fitting a common trend was adequate, for each summer date (Aug. 2013, June 2014, July 2014, and Aug. 2014) and for the response variables $\mathrm{P}_{\mathrm{n}}$ and SPAD, a nonlinear broken lines model with a line segment and plateau (Robbins et al., 2006) was fit with leaf tissue $\mathrm{Zn}$ concentration as the explanatory variable. Only observations with leaf tissue $\mathrm{Zn}$ concentrations $50 \mathrm{mg} \cdot \mathrm{kg}^{-1}$ or lower were used. Fitted models are presented graphically with the $95 \%$ confidence interval (CI) breakpoint estimate. The preliminary analysis combined data from the four summer dates and fitted two mixed nonlinear models. Both models accounted for random tree effects within year and included a line segment-plateau trend in the fixed portion. The first model fit separate broken lines to each date and the second model fit a single broken line to all four dates. The models were compared using likelihood ratio tests which suggested the need to fit separate trends to the four dates $(P \leq 0.05)$. The broken lines models were fit using PROC NLMIXED software (SAS version 9.3).

\section{Results and Discussion}

The leaf tissue $\mathrm{Zn}$ concentrations by dry weight were significantly different between the untreated Control and the Zn-EDTAtreated trees on all of the tissue sampling dates in 2013 and 2014 (Fig. 1). Generally, average leaf $\mathrm{Zn}$ concentrations of the trees receiving the lower soil $\mathrm{Zn}$-EDTA application rate were about double that of the Control and leaf $\mathrm{Zn}$ concentrations of the trees receiving the higher soil Zn-EDTA application rate were about triple that of the Control. In 2013, the treatment $\times$ date interaction was not significant and leaf $\mathrm{Zn}$ concentrations averaged across the two sampling dates were $( \pm \mathrm{SE}) 9.6 \pm 0.8$ $\mathrm{mg} \cdot \mathrm{kg}^{-1}$ for the Control, $18.8 \pm 2.4 \mathrm{mg} \cdot \mathrm{kg}^{-1}$ for the $\mathrm{Zn} 1$ treatment, and $31.2 \pm 4.4 \mathrm{mg} \cdot \mathrm{kg}^{-1}$ for the $\mathrm{Zn} 2$ treatment. Although pairs of $\mathrm{Zn}$ treatment averages differed in the preplanned analysis, when fitting separate variances to each treatment group, the difference between the $\mathrm{Zn} 2$ average and Zn1 average across the two sampling dates in 2013 was just short of significant $\left[12.5 \pm 5.0 \mathrm{mg} \cdot \mathrm{kg}^{-1}(P=0.059)\right]$. The interaction was not significant in 2014 and across the five sampling dates in 2014, average leaf tissue $\mathrm{Zn}$ concentration was lower for the untreated Control $\left(11.4 \pm 0.6 \mathrm{mg} \cdot \mathrm{kg}^{-1}\right)$, than for the $\mathrm{Zn} 1$ treatment $\left(22.6 \pm 2.6 \mathrm{mg} \cdot \mathrm{kg}^{-1}\right)$ or the $\mathrm{Zn} 2$ treatment $\left(31.3 \pm 5.3 \mathrm{mg} \cdot \mathrm{kg}^{-1}\right)$ (Fig. 1). Tissue Zn concentrations for the Control, Zn1, and Zn2 in 2012 were 9.6, 18.6, and $25.4 \mathrm{mg} \cdot \mathrm{kg}^{-1}$, respectively (data not presented). On every tissue sampling date during the 3 years of the study, the average leaf concentrations of even the $\mathrm{Zn} 2$ treatment were well below the current extension recommendations of $50-100 \mathrm{mg} \cdot \mathrm{kg}^{-1}$ (Heerema, 2013).

The positive influence of soil applied Zn-EDTA and consequent increase in leaf $\mathrm{Zn}$ on leaf net $\mathrm{P}_{\mathrm{n}}$ of immature 

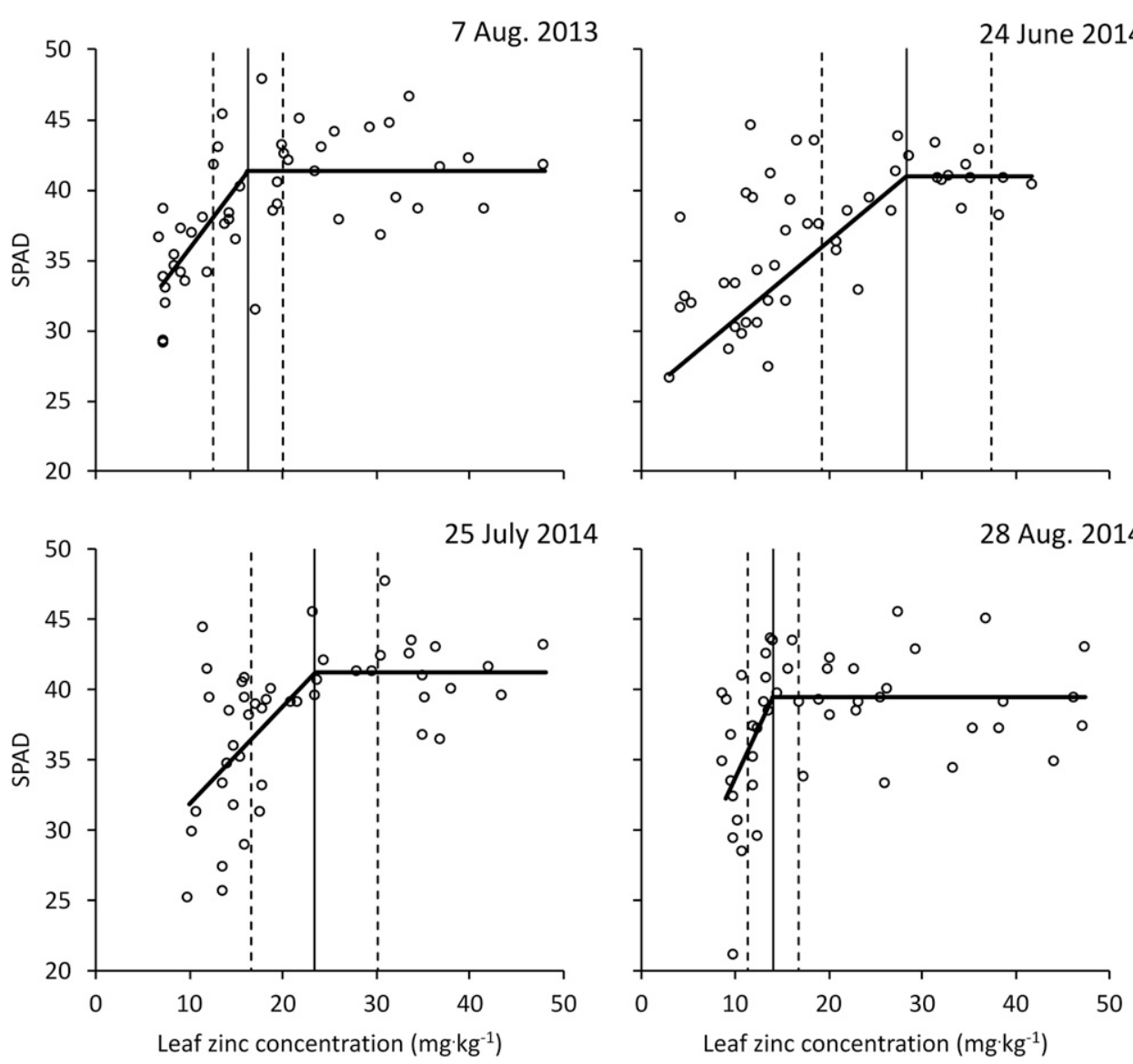

Fig. 5. The relationship of leaf SPAD to leaf $\mathrm{Zn}$ concentration (by dry weight) in 'Wichita' pecan trees on $7 \mathrm{Aug}$. $2013\left(r^{2}=0.47\right), 24$ June $2014\left(r^{2}=0.44\right), 25$ July $2014\left(r^{2}=0.39\right)$, and 28 Aug. $2014\left(r^{2}=0.29\right)$ measurement occasions. The solid vertical line represents the breakpoint leaf $\mathrm{Zn}$ tissue concentration below which leaf photosynthesis begins to decline. Dashed vertical lines represent the $95 \%$ confidence interval for the breakpoint.

'Wichita' pecan trees was sizeable. Leaf $\mathrm{P}_{\mathrm{n}}$ was significantly higher for trees in both soil $\mathrm{Zn}$ treatments than for trees in the Control on every measurement date except 1 Oct. 2014 (Fig. 2). Leaf $\mathrm{P}_{\mathrm{n}}$ of the two soil Zn-EDTA treatments were not significantly different from each other on any measurement date during the three seasons of the study (Fig. 2). Across dates, the low and high soil Zn-EDTA treatments increased $\mathrm{P}_{\mathrm{n}}$ over the Control by $17.1 \%$ and $25.1 \%$, respectively, in 2012 ; by $35.3 \%$ and $40.5 \%$, respectively, in 2013 ; and by $62.7 \%$ and $65.8 \%$, respectively, in 2014. Much of the positive response in growth, overall tree health, nut production, and kernel quality of soil Zn-EDTA-treated 'Wichita' pecan trees (Walworth et al., 2016; Wang, 2016) could likely be accounted for by the higher leaf-level carbon assimilation rates measured in the current study. Furthermore, the impacts of such increases in $P_{n}$ at the leaf level on total tree-wide carbon assimilation is expected to be greatly magnified in the $\mathrm{Zn}$-treated trees by the larger tree size (Walworth et al., 2016) and, presumably, higher leaf area index.

$\mathrm{Hu}$ and Sparks (1991) showed that leaf $\mathrm{P}_{\mathrm{n}}$ of $\approx 60$-year-old 'Stuart' pecan trees in mid-August increased with increasing leaf tissue $\mathrm{Zn}$ concentration and leaf $\mathrm{P}_{\mathrm{n}}$ was approaching, but had not yet reached, maximum levels at $14.3 \mathrm{mg} \cdot \mathrm{kg}^{-1} \mathrm{Zn}$ (leaves with tissue $\mathrm{Zn}$ concentration $>14.3 \mathrm{mg} \cdot \mathrm{kg}^{-1}$ were not included in that study). In our experiment, when leaf $\mathrm{P}_{\mathrm{n}}$ was modeled as a function of leaf tissue $\mathrm{Zn}$ concentration (by dry
0.89 (24 June 2014), 0.69 (25 July 2014), and 1.25 (28 Aug. 2014) $\mu \mathrm{mol} \cdot \mathrm{m}^{-2} \cdot \mathrm{s}^{-1}$ for every increase of $1 \mathrm{mg} \cdot \mathrm{kg}^{-1} \mathrm{Zn}$ (Fig. 3). Plateau leaf $\mathrm{P}_{\mathrm{n}}$ values above the breakpoints for the 7 Aug. 2013, 25 July 2014, and 28 Aug. 2014 measurement occasions were similar to one another, ranging from 16.1 to $16.6 \mu \mathrm{mol} \cdot \mathrm{m}^{-2} \cdot \mathrm{s}^{-1}$, but the plateau $\mathrm{P}_{\mathrm{n}}$ value on the 24 June 2014 measurement occasion was 18.8 $\mu \mathrm{mol} \cdot \mathrm{m}^{-2} \cdot \mathrm{s}^{-1}$ (Fig. 3). Although the mean $\mathrm{P}_{\mathrm{n}}$ values at optimal $\mathrm{Zn}$ (i.e., the maximum estimated $\mathrm{P}_{\mathrm{n}}$ values) in our study were slightly lower than $\mathrm{Hu}$ and Sparks (1991) reported for pecan $\left(16-19 \mu \mathrm{mol} \cdot \mathrm{m}^{-2} \cdot \mathrm{s}^{-1}\right.$ in the present study vs. $>20 \mu \mathrm{mol} \cdot \mathrm{m}^{-2} \cdot \mathrm{s}^{-1}$ in their study), the overall relationships between leaf $Z n$ and $P_{n}$ were similar. Our data and those of Hu and Sparks (1991) show that maximum leaf $\mathrm{P}_{\mathrm{n}}$ for pecan may be achieved at leaf tissue $\mathrm{Zn}$ concentrations much lower than the extension recommended range for $\mathrm{Zn}$ of $50-100 \mu \mathrm{mol} \cdot \mathrm{m}^{-2} \cdot \mathrm{s}^{-1}$ (Heerema, 2013).

The SPAD (leaf greenness) index of trees in both soil $\mathrm{Zn}$ treatments was significantly higher than the Control on every measurement date during the three seasons of the study (Fig. 4). The soil $\mathrm{Zn}$ treatment by date interaction for SPAD was significant in 2014, but was not significant in 2013. Low leaf SPAD in the Control indicated the onset of interveinal chlorosis, which is widely accepted as part of the syndrome of visible symptoms associated with $\mathrm{Zn}$ deficiency in plants and a loss of chlorophyll from the leaf photosynthetic tissues (Broadley et al., 2012). Trees in the $\mathrm{Zn} 2$ treatment had significantly higher leaf SPAD than the trees in the $\mathrm{Zn} 1$ 

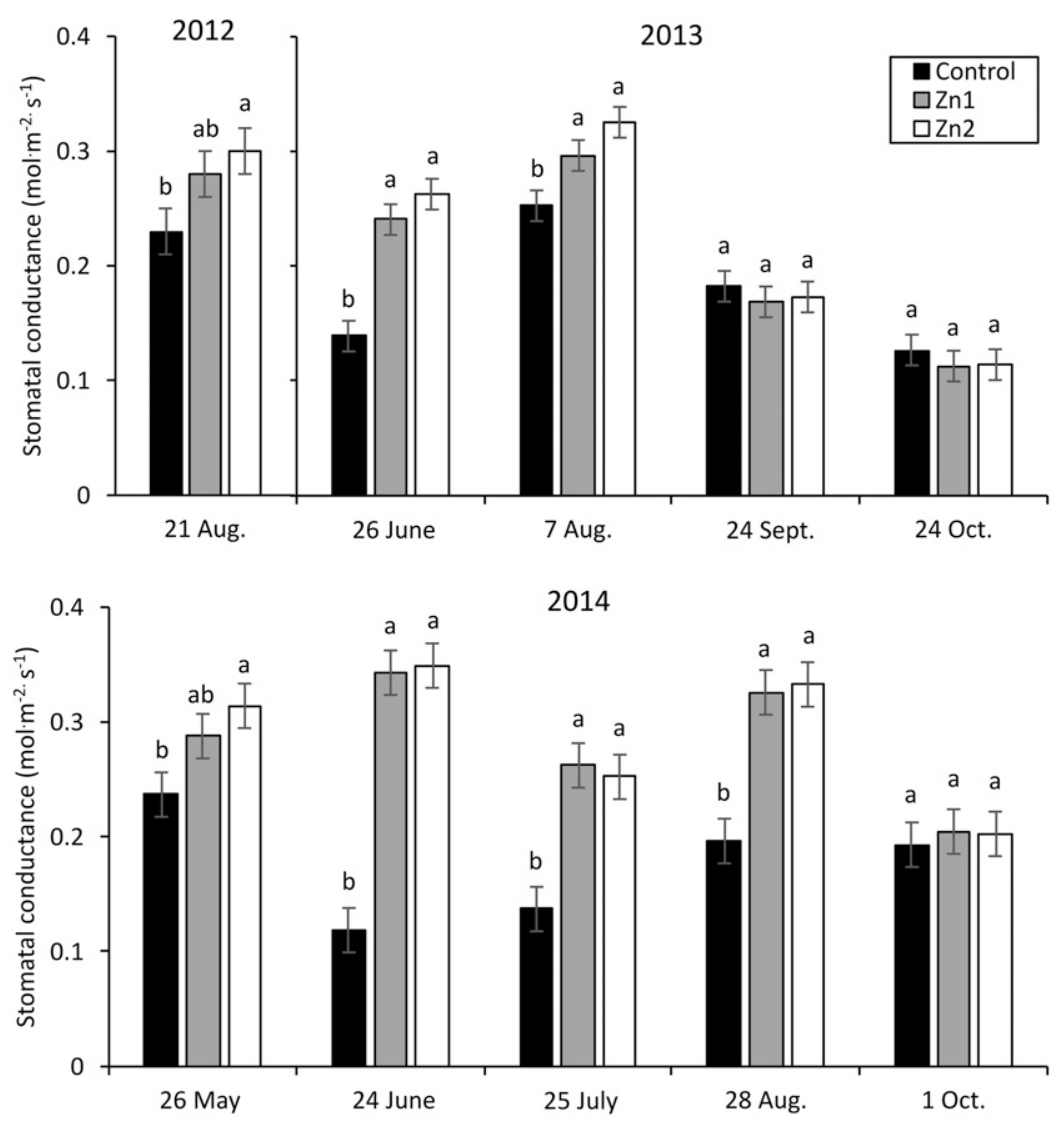

Fig. 6. Stomatal conductance to water vapor of leaves from immature 'Wichita' pecan trees receiving soil applications of $\mathrm{Zn}$-ethylenediaminetetraacetic acid at annual rates of $2.2 \mathrm{~kg} \cdot \mathrm{ha}^{-1} \mathrm{Zn}$ [Zn1 (gray bars)] or $4.4 \mathrm{~kg} \cdot \mathrm{ha}^{-1} \mathrm{Zn}$ [Zn2 (white bars)] beginning in 2011. Trees in the Control (black bars) received no $\mathrm{Zn}$ fertilizer. Data are least squares means \pm model-based SE. Within measurement occasion (date), least squares means accompanied by the same lower-case letter are not significantly different $(\alpha=0.05)$ by F-protected least significant difference.

treatment (SPAD 34.8 vs. 32.3) on 26 May 2014, but leaf SPAD values of trees in the two soil $\mathrm{Zn}$ treatments were not significantly different from each other on any of the other measurement occasions throughout the study (Fig. 4). Consistent with our leaf SPAD results, strong direct relationships between $\mathrm{Zn}$ nutrition and leaf content of chlorophyll or SPAD have been previously shown in diverse plant species including pecan (Fu et al., 2015; Hu and Sparks, 1991; Mukhopadhyay et al., 2013; Ojeda-Barrios et al., 2012; Tavallali et al., 2009).

Leaf SPAD, also modeled as a function of leaf tissue $\mathrm{Zn}$ concentration using a broken-lines regression model with a line segment-plateau form, showed breakpoints at leaf tissue $\mathrm{Zn}$ concentration of $16.3 \mathrm{mg} \cdot \mathrm{kg}^{-1}\left(95 \% \mathrm{CI}=12.5-20.0 \mathrm{mg} \cdot \mathrm{kg}^{-1}\right)$ by dry weight on 7 Aug. 2013 and $14.1 \mathrm{mg} \cdot \mathrm{kg}^{-1}(95 \% \mathrm{CI}=11.4$ $16.8 \mathrm{mg} \cdot \mathrm{kg}^{-1}$ ) by dry weight on $28 \mathrm{Aug} .2014$ (Fig. 5). As leaf tissue $\mathrm{Zn}$ concentration fell below the breakpoints, leaf SPAD fell at a rate of $0.88 \mathrm{SPAD}$ units for every $1 \mathrm{mg} \cdot \mathrm{kg}^{-1} \mathrm{Zn}$ decline in leaf tissue $\mathrm{Zn}$ concentration on the 7 Aug. 2013 measurement occasion and $1.4 \mathrm{mg} \cdot \mathrm{kg}^{-1}$ on $28 \mathrm{Aug}$. 2014. As with $\mathrm{P}_{\mathrm{n}}$, the breakpoint was higher on the 24 June $2014\left[28.3 \mathrm{mg} \cdot \mathrm{kg}^{-1}(95 \%\right.$ $\left.\left.\mathrm{CI}=19.3-37.4 \mathrm{mg} \cdot \mathrm{kg}^{-1}\right)\right]$ and $25 \mathrm{July} 2014\left[23.4 \mathrm{mg} \cdot \mathrm{kg}^{-1}(95 \%\right.$ $\left.\left.\mathrm{CI}=16.6-30.1 \mathrm{mg} \cdot \mathrm{kg}^{-1}\right)\right]$ measurement occasions than on the August measurement occasions in 2013 and 2014 (Fig. 5). Mean leaf SPAD values above the $\mathrm{Zn}$ concentration breakpoint were similar (ranging from SPAD 39 to 41) on all four of the midseason measurement occasions (Fig. 5).
The soil $\mathrm{Zn}$ treatment by date interaction for $g_{\mathrm{s}}$ to water vapor was significant in both 2013 and 2014. Stomatal conductance in Zn2 treatment trees was significantly higher than that of the trees in the Control on all early through midseason measurement occasions [May through August (Fig. 6)]. Average $g_{\mathrm{s}}$ of trees in the $\mathrm{Zn} 1$ treatment was not significantly different from that of the $\mathrm{Zn} 2$ treatment on any of the measurement occasions during the study (Fig. 6). During early and midseason, $\mathrm{Zn} 1$ had significantly higher $g_{\mathrm{s}}$ than the Control on all dates except 21 Aug. 2012 and 26 May 2014 (Fig. 6). On all late season measurement dates (i.e., in September and October), overall $g_{s}$ was noticeably lower than on early and midseason measurement dates and there were no significant differences in $g_{\mathrm{s}}$ among the three treatments (Fig. 6 ). The different behavior of $g_{s}$ in the late season may have been due to the onset of early autumn leaf senescence or to the grower ending irrigation in preparation for winter [which would be consistent with the unusually low MDSWP measured on 24 Oct. 2013 (data not presented)]. The difference in $g_{\text {s }}$ between the $\mathrm{Zn}$ treated vs. the Control trees was greatest on the June measurement occasions, especially in 2014 when $g_{\text {s }}$ of the Control was only $34 \%$ of that of $\mathrm{Zn} 2$ trees [0.1187 vs. $0.3491 \mathrm{~mol} \cdot \mathrm{m}^{-2} \cdot \mathrm{s}^{-1}$ (Fig. 6)]. In contrast with SPAD and $\mathrm{P}_{\mathrm{n}}$, there was no consistent evidence that $g_{\mathrm{s}}$ exhibited the line segment-plateau form in relation to leaf tissue $\mathrm{Zn}$ concentration using broken-lines regression analyses (data not presented).

As expected, transpiration measured at the leaf level followed the same pattern as $g_{\text {s }}$ (data not presented). Along with larger tree canopy size associated with $\mathrm{Zn}$ applications (Walworth et al., 2016), increased $g_{\mathrm{s}}$ and transpiration, could have implications for pecan orchard water use, irrigation scheduling, and water use efficiency as has been shown for other crops. For example, water use by Zn-sufficient chickpea (Cicer arietinum) plants was higher than that of Zn-deficient plants, but water use efficiency also increased (Khan et al., 2004). And, in cauliflower (Brassica oleracea var. botrytis) grown in sand culture, a significant increase in leaf water potential accompanied higher tissue $\mathrm{Zn}$ concentration, $\mathrm{P}_{\mathrm{n}}, g_{\mathrm{s}}$, and transpiration rates when $\mathrm{Zn}$ fertilizer was supplied at "normal" vs. "deficient" rates (Sharma et al., 1994). In our study, acceptable plant water status (as MDSWP) was usually observed across $\mathrm{Zn}$ treatments, but across measurement occasions, the percent increase in transpiration with the soil $\mathrm{Zn}$ treated trees compared with Control trees was far less than that of $P_{n}$ (about one-half to two-thirds that for $P_{n}$ in 2013 and 2014, respectively). Although it will require further investigation to confirm, this suggests that water use efficiency of 'Wichita' pecan improved with soil Zn-EDTA applications.

Intercellular $\mathrm{CO}_{2}$ concentration was not significantly different among the Control and two soil $\mathrm{Zn}$ treatments on $21 \mathrm{Aug}$. 2012 and the early season (May-June) measurement occasions in 2013 and 2014 (Fig. 7). On the other six midlate season 

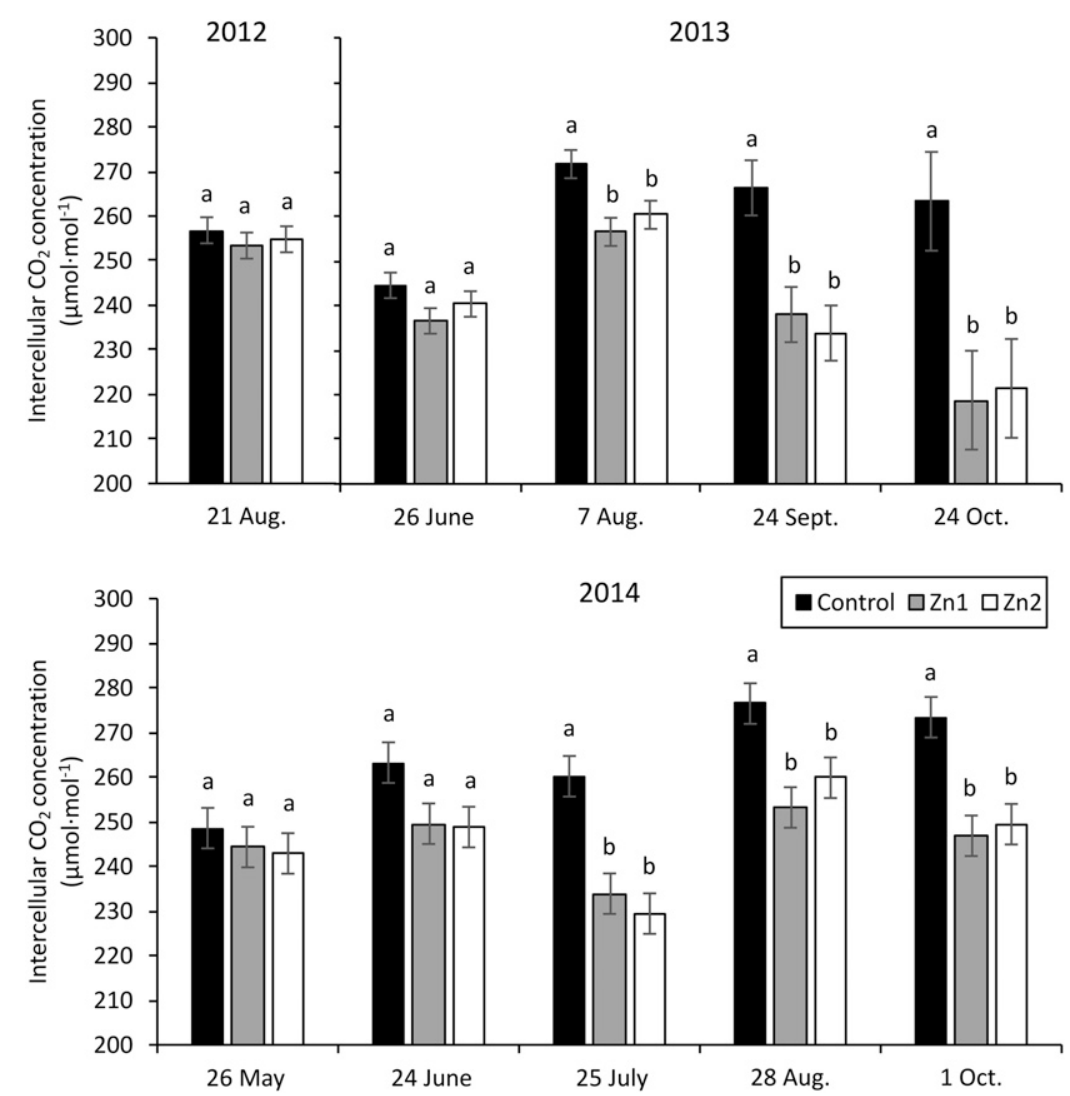

Fig. 7. Intercellular $\mathrm{CO}_{2}$ concentration $\left(\mathrm{C}_{\mathrm{i}}\right)$ of leaves from immature 'Wichita' pecan trees receiving soil applications of $\mathrm{Zn}$-ethylenediaminetetraacetic acid at annual rates of $2.2 \mathrm{~kg} \cdot \mathrm{ha}^{-1} \mathrm{Zn}[\mathrm{Zn} 1$ (gray bars)] or $4.4 \mathrm{~kg} \cdot \mathrm{ha}^{-1} \mathrm{Zn}$ [Zn2 (white bars)] beginning in 2011. Trees in the Control (black bars) received no $\mathrm{Zn}$ fertilizer. Data are least squares means \pm model-based SE. Within measurement occasion (date), least squares means accompanied by the same lower-case letter are not significantly different $(\alpha=0.05)$ by F-protected least significant difference. The soil $\mathrm{Zn}$ treatment by date interaction for $\mathrm{C}_{\mathrm{i}}$ was not significant in either $2013(P=0.06)$ or $2014(P=0.10)$.

measurement occasions in 2013 and 2014, $\mathrm{C}_{\mathrm{i}}$ was significantly higher for leaves of Control trees than for leaves in the two soil $\mathrm{Zn}$ treatments (Fig. 7). The $\mathrm{Zn}$ treatment main effect was significant but the $\mathrm{Zn}$ treatment by date interaction for $\mathrm{C}_{\mathrm{i}}$ was not significant in either 2013 or 2014. This indicates an increase in Calvin cycle $\mathrm{CO}_{2}$ demand relative to the $\mathrm{CO}_{2}$ supply rate from the atmosphere through the stomata of the leaves of $\mathrm{Zn}$ sufficient pecan trees compared with that of $\mathrm{Zn}$-deficient trees. Nonetheless, $C_{i}$ was not significantly different between the two $\mathrm{Zn}$ treatments on any of the measurement dates (Fig. 7) or averaged across dates.

That there was a significant reduction in $\mathrm{C}_{\mathrm{i}}$ of $\mathrm{Zn}$-treated trees in 2013 and 2014 that persisted even late into the season [i.e., September and October (Fig. 7)] when differences in $g_{\mathrm{s}}$ had disappeared (Fig. 6) suggests that soil $\mathrm{Zn}$ applications alleviated nonstomatal limitations to $P_{n}$ caused by $\mathrm{Zn}$ deficiency. Although it is possible that there were also direct effects of Zn nutrition on guard cell control of $g_{\mathrm{s}}$ (Cakmak, 2000; Sharma et al., 1995), it seems most likely in our study that the increased $g_{\mathrm{s}}$ measured in the pecan trees receiving soil-applied $\mathrm{Zn}$ was due primarily to a stomatal response to increased demand for $\mathrm{CO}_{2}$ by the leaf photosynthetic apparatus (Calvin cycle reactions) and the consequent depression of $C_{i}$ (Assmann, 1993). Additional research, including analysis of carbon assimilation (A): $C_{i}$ relationships $\left(A: C_{i}\right.$ curves), is needed to determine the relative importance of nonstomatal and stomatal factors in $\mathrm{Zn}$ nutrition effects on improving pecan $\mathrm{P}_{\mathrm{n}}$.

In summary, Zn-EDTA application via fertigation in this alkaline, calcareous soil increased leaf $\mathrm{Zn}$ concentration and $\mathrm{P}_{\mathrm{n}}$ of immature 'Wichita' pecan trees with optimal $\mathrm{P}_{\mathrm{n}}$ in midseason (June-August) occurring at leaf $\mathrm{Zn}$ concentrations as low as 14-22 $\mathrm{mg} \cdot \mathrm{kg}^{-1}$. Zinc-EDTA applications appear to increase $\mathrm{P}_{\mathrm{n}}$ through alleviating nonstomatal limitations, including low tissue chlorophyll levels, but direct effects on $g_{\mathrm{s}}$ in early and midseason are also possible.

\section{Literature Cited}

Alben, A.O., J.R. Cole, and R.D. Lewis. 1932a. Chemical treatment of pecan rosette. Phytopathology 22:595-601.

Alben, A.O., J.R. Cole, and R.D. Lewis. 1932b. New developments in treating pecan rosette with chemicals. Phytopathology 22:979-981.

Amiri, A., B. Baninasab, C. Ghobadi, and A.H. Khoshgoftarmanesh. 2016. Zinc soil application enhances photosynthetic capacity and antioxidant enzyme activities in almond seedlings affected by salinity stress. Photosynthetica 54:267-274.

Anderson, P.C. 1994. Temperate nut species, p. 299-338. In: B. Schaffer and P.C. Anderson (eds.). Handbook of environmental physiology of fruit crops. Vol I: Temperate crops. CRC Press, New York, NY.

Assmann, S.M. 1993. Signal-transduction in guard-cells. Annu. Rev. Cell Biol. 9:345-375.

Broadley, M.R., P.H. Brown, I. Cakmak, Z. Rengel, and F. Zhao. 2012. Function of nutrients: Micronutrients, p. 191-248. In: P. Marschner (ed.). Marschner's mineral nutrition of higher plants. 3rd ed. Academic Press, San Diego, CA.

Broadley, M.R., P.J. White, J.P. Hammond, I. Zelko, and A. Lux. 2007. Zinc in plants. New Phytol. 173:677-702.

Brown, P.H., I. Cakmak, and Q. Zhang. 1993. Form and function of zinc plants, p. 93-106. In: A.D. Robson (ed.). Proc. Intl. Symp. Zinc in Soils and Plants. Developments in plant and soil science. Vol. 55. Springer, Dordrecht, The Netherlands.

Cakmak, I. 2000. Possible roles of zinc in protecting plant cells from damage by reactive oxygen species. New Phytol. 146:185-205.

Chandler, W.H. 1937. Zinc as a nutrient for plants. Bot. Gaz. 98:625646.

Fenn, L.B., H.L. Malstrom, T. Riley, and G.L. Horst. 1990. Acidification of calcareous soils improves zinc-absorption of pecan trees. J. Amer. Soc. Hort. Sci. 115:741-744.

Fu, C.X., M. Li, Y. Zhang, Y.Z. Zhang, Y.J. Yan, and Y.A. Wang. 2015. Morphology, photosynthesis, and internal structure alterations in field apple leaves under hidden and acute zinc deficiency. Sci. Hort. 193:47-54.

Heerema, R. 2013. Diagnosing nutrient disorders of New Mexico pecan trees. New Mexico State Univ. Ext. Bul. H-658. 10 May 2016. $<$ http://aces.nmsu.edu/pubs/_h/H658.pdf $>$.

Herrera, E. 2005. Pecan varieties for New Mexico. New Mexico State Univ. Ext. Bul. H-639.27 May 2016. <http://aces.nmsu.edu/pubs/_h/ H639.pdf>.

$\mathrm{Hu}$, H. and D. Sparks. 1990. Zinc-deficiency inhibits reproductive development in 'Stuart' pecan. HortScience 25:1392-1396. 
Hu, H. and D. Sparks. 1991. Zinc-deficiency inhibits chlorophyll synthesis and gas-exchange in 'Stuart' pecan. HortScience 26:267268.

Imtiaz, M., B.J. Alloway, M. Aslam, M.Y. Memon, P. Khan, S.U.H. Siddiqui, and S.K.H. Shah. 2006. Zinc sorption in selected soils. Commun. Soil Sci. Plant Anal. 37:1675-1688.

Jones, J.B. and V.W. Case. 1990. Sampling, handling, and analyzing plant tissue samples, p. 389-427. In: R.L. Westerman (ed.). Soil testing and plant analysis. 3rd ed. Soil Sci. Soc. Amer., Madison, WI.

Khan, H.R., G.K. McDonald, and Z. Rengel. 2004. Zinc fertilization and water stress affects plant water relations, stomatal conductance and osmotic adjustment in chickpea (Cicer arientinum L.). Plant Soil 267:271-284.

Lombardini, L., H. Restrepo-Diaz, and A. Volder. 2009. Photosynthetic light response and epidermal characteristics of sun and shade pecan leaves. J. Amer. Soc. Hort. Sci. 134:372-378.

Marschner, H. 1993. Zinc uptake from soils, p. 59-77. In: A.D. Robson (ed.). Proc. Intl. Symp. Zinc in Soils and Plants. Developments in plant and soil science. Vol. 55. Springer, Dordrecht, The Netherlands.

Mattiello, E.M., H.A. Ruiz, J.C.L. Neves, M.C. Ventrella, and W.L. Araujo. 2015. Zinc deficiency affects physiological and anatomical characteristics in maize leaves. J. Plant Physiol. 183:138-143.

Mukhopadhyay, M., A. Das, P. Subba, P. Bantawa, B. Sarkar, P. Ghosh, and T.K. Mondal. 2013. Structural, physiological, and biochemical profiling of tea plants under zinc stress. Biol. Plant. 57:474480.

Núñez-Moreno, H., J.L. Walworth, and A.P. Pond. 2009a. Manure and soil zinc application to 'Wichita' pecan trees growing under alkaline conditions. HortScience 44:1741-1745.

Núñez-Moreno, H., J.L. Walworth, A.P. Pond, and M.W. Kilby. 2009b. Soil zinc fertilization of 'Wichita' pecan trees growing under alkaline soil conditions. HortScience 44:1736-1740.

Ojeda-Barrios, D., J. Abadía, L. Lombardini, A. Abadía, and S. Vázquez. 2012. Zinc deficiency in field-grown pecan trees: Changes in leaf nutrient concentrations and structure. J. Sci. Food Agr. 92:1672-1678.

Othman, Y., D. VanLeeuwen, R. Heerema, and R. St. Hilaire. 2014. Midday stem water potential values needed to maintain photosynthesis and leaf gas exchange established for pecan. J. Amer. Soc. Hort. Sci. 139:537-546.

Robbins, K.R., A.M. Saxton, and L.L. Southern. 2006. Estimation of nutrient requirements using broken-lines regression analysis. J. Anim. Sci. 84(suppl):E155-E165.

Servicio de Información Agroalimentaria Pesquera. 2014. Producción Agropecuaria y Pesquera. 6 May 2016. <http://www.siap.gob.mx/>. Shackel, K.A., H. Ahmadi, W. Biasi, R. Buchner, D. Goldhamer, S. Gurusinghe, J. Hasey, D. Kester, B. Krueger, B. Lampinen, G. McGourty, W. Micke, E. Mitcham, B. Olson, K. Pelletrau, H. Philips, D. Ramos, L. Schwankl, S. Sibbett, R. Snyder, S. Southwick, M. Stevenson, M. Thorpe, S. Weinbaum, and J. Yeager. 1997. Plant water status as an index of irrigation need in deciduous fruit trees. HortTechnology 7:23-29.

Sharma, P.N., N. Kumar, and S.S. Bisht. 1994. Effect of zincdeficiency on chlorophyll content, photosynthesis and water relations of cauliflower plants. Photosynthetica 30:353-359.

Sharma, P.N., A. Tripathi, and S.S. Bisht. 1995. Zinc requirement for stomatal opening in cauliflower. Plant Physiol. 107:751-756.

Tavallali, V., M. Rahemi, M. Maftoun, B. Panahi, S. Karimi, A. Ramezanian, and M. Vaezpour. 2009. Zinc influence and salt stress on photosynthesis, water relations, and carbonic anhydrase activity in pistachio. Sci. Hort. 123:272-279.

University of Arizona. 2016. AZMET: The Arizona meteorological network, San Simon station data and reports. 14 June 2016. $<$ https:// ag.arizona.edu/azmet/37.htm>.

U.S. Department of Commerce. 2016. Earth system research laboratory/ NOAA trends in atmospheric $\mathrm{CO}_{2}$. 21 June 2016. <http://www.esrl. noaa.gov/gmd/ccgg/trends/global.html>.

U.S. Department of Agriculture (USDA). 2011. Official soil series descriptions: Guest series. 20 Sept. 2016. $<$ https://soilseries.sc.egov. usda.gov/OSD_Docs/G/GUEST.html>.

U.S. Department of Agriculture (USDA). 2012. United States census of agriculture. 6 May 2016. $<$ https://www.agcensus.usda.gov/>.

U.S. Department of Agriculture (USDA). 2016a. Web soil survey. 12 June 2016. <http://websoilsurvey.sc.egov.usda.gov/App/ WebSoilSurvey.aspx $>$.

U.S. Department of Agriculture (USDA). 2016b. Ecological site description system: Climate features. 14 June 2016. $<$ https://esis. sc.egov.usda.gov/ESDReport/fsReport.aspx?id=R041XB204AZ $\&$ rptLevel $=$ climate $\&$ approved $=$ yes $\&$ rep Type $=$ regular $\&$ scrns $=\&$ comm $=>$.

U.S. Geological Survey. 2016. Digital representations of tree species range maps from "Atlas of United States trees" by Elbert L. Little, Jr. (and other publications). 24 Aug. 2016. $<$ http://gec.cr.usgs.gov/data/ little/>.

Vallee, B.L. and D.S. Auld. 1990. Zinc coordination, function, and structure of zinc enzymes and other proteins. Biochemistry 29:56475659.

Walworth, J.L., A.P. Pond, and M.W. Kilby. 2006. Leaf sampling guide with interpretation for Arizona pecan orchards. Univ. Arizona Coop. Ext. Guide AZ1410. 22 June 2016. <http://extension.arizona. edu/sites/extension.arizona.edu/files/pubs/az1410.pdf $>$.

Walworth, J.L., S.A. White, M.J. Comeau, and R.J. Heerema. 2016. Soil-applied ZnEDTA: Vegetative growth, nut production and nutrient acquisition of immature pecan grown on an alkaline, calcareous soil. HortScience (In press).

Wang, Y. 2016. The nutraceutical properties including antioxidant capacity of 'Wichita' and 'Western' pecan kernels are affected by soil zinc fertilizer application. MS Thesis, New Mexico State Univ., Las Cruces, NM.

Yruela, I. 2013. Transition metals in plant photosynthesis. Metallomics 5:1090-1109. 